\title{
Az új generációs közúti pályaszerkezetek jellemzőinek feltárása
}

A közúti közlekedési rendszer jelentős változáson megy keresztül. $\mathrm{Az}$ elemek és alrendszerek fejlődésére külső, környezeti és belső, jármü-pálya-ember közötti kölcsönhatások is hatással vannak. Ennek megfelelően, a közúti pályaszerkezet, valamint az infrastruktúra innovációját az aktuális technológiai és a jármüfejlesztések alapvetően befolyásolják. Hazánkban az intelligens pályaszerkezetekkel kapcsolatos ismeretanyag még hiányos, ezért a kutatás célja a nemzetközi kutatás-fejlesztési tapasztalatok tanulmányozása és elemzése, a hazai adaptáció elősegítése.

DOI $10.24228 / K T S Z .2018 .6 .4$

\section{Balog Péter ${ }^{1}$ - Dr. Csiszár Csaba ${ }^{1}$ - Dr. Tóth Csaba²}

BME Közlekedésüzemi és Közlekedésgazdasági Tanszék Út és Vasútépítési Tanszék ${ }^{2}$

e-mail: pbalog1993@gmail.com, csiszar.csaba@mail.bme.hu, toth.csaba@epito.bme.hu

\section{BEVEZETÉS}

Az Európai Unió az elektromos közlekedés és az autonóm járműirányítás széles körü terjedését, valamint a környezet fokozott megóvását stratégiai céljának tekinti. Ennek megfelelően ösztönzi a közlekedési és a telekommunikációs ágazatok összekapcsolását. A közlekedésnek jelentős kihívásokkal kell megküzdenie az elkövetkező évtizedekben, hogy a gazdaság és a társadalom mobilitási igényeinek megfeleljen. Ezért az utóbbi években számos irányelvet fogalmaztak meg az új technológiákkal és a környezeti fenntarthatósággal összefüggésben [2] [3] [4], amelyek közül kiemelten kezelendő a 2010/40/EU Irányelv. Az Intelligens Közlekedési Rendszerek (Intelligent Transport System, ITS) Direktíva fogalmazza meg a közlekedés „okos” fejlesztésének keretét, meghatározza az ITS rendszerek alkalmazásának területeit és a javasolt intézkedéseket. A direktíva elsősorban a közúti közlekedés jövőjével kapcsolatban ad iránymutatást; meghatározza, hogy milyen kapcsolódási pontjai legyenek más közlekedési alrendszerekhez, elősegítve a multimodális megoldásokat. Kiemeli, hogy a közúti közlekedési alrendszeren belül és a kapcsolódó alrendszerek tekintetében is biztosítani kell az információk áramlását.

Az okos utak (smart roads) a jövőben nemcsak a személyek és a járművek mozgásának lehetőségét fogják biztosítani számos funkció (adatgyüjtés, kommunikáció, információ menedzsment) segítségével, hanem a jövő közútjai, útpályaszerkezetei ezen felül intelligensek lesznek: - a gyártás és a beépítés során előtérbe kerülnek a fenntartható és a környezetkímélő megoldások, illetve növekvő arányban jelennek meg az újrahasznosított anyagok; 


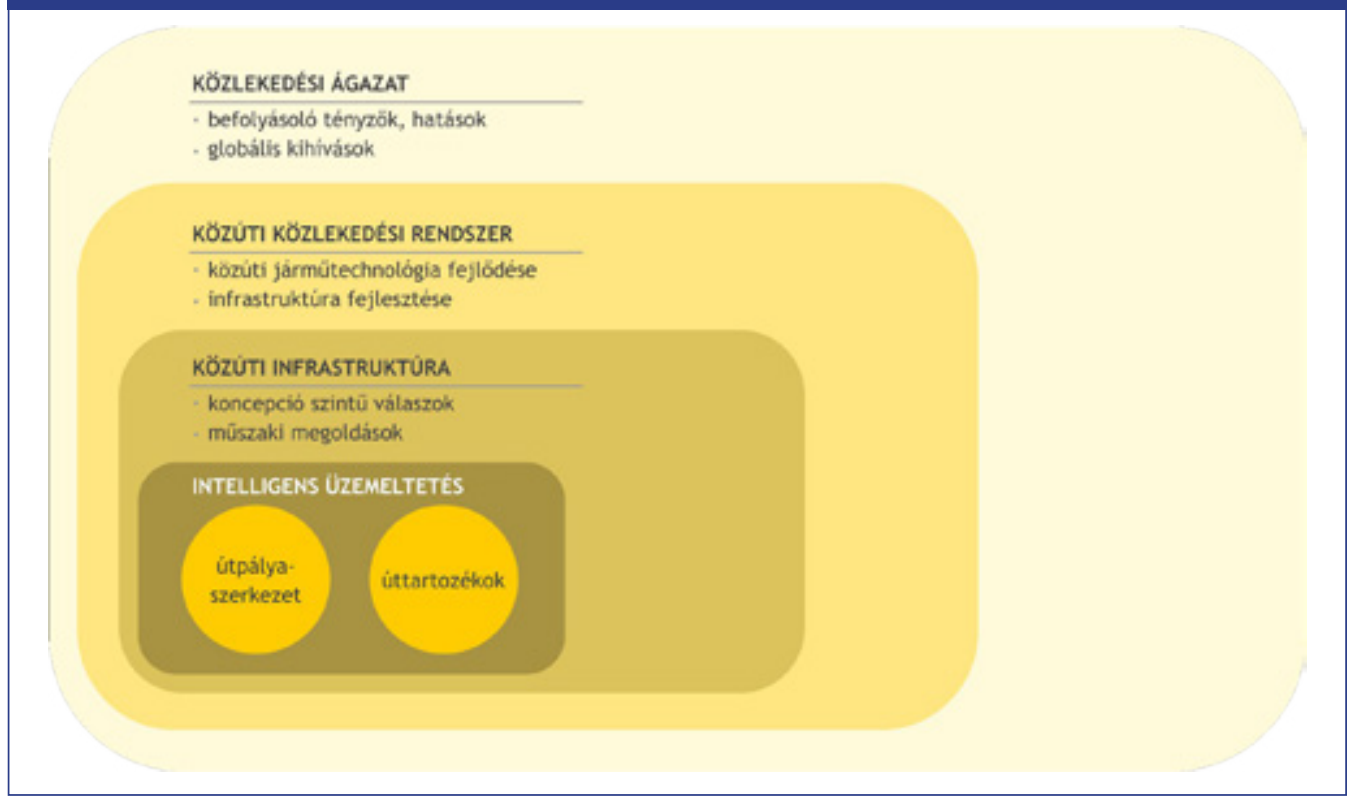

- előtérbe kerülnek a hosszú élettartamú és a jól fenntartható, gyorsan javítható vagy cserélhető pályaszerkezetek és úttartozékok;

- az elektromos jármüvek csökkentik a károsanyag-kibocsátást; azonban az akkumulátor kapacitása és a töltési idő a technológia fejlesztésének nagy kihívása, amelyet az intelligens útpályaszerkezet (energiatermelés, induktív töltés) oldhat meg;

- az útpályaszerkezetek nem csak a jármüvek számára biztosítanak információkat, hanem az üzemeltetéshez is (pl. intelligens világítás, automata síkosságmentesítés);

- az önvezetö járművek érzékelése (pl. radar, lidar, kamerák, szenzorok) a burkolati jeleken és az úttartozékokon alapul, azok állapota, minősége és intelligens fejlesztési iránya kiemelt fontosságú.

A globális kihívások a közlekedés valamennyi alrendszerének fejlődésére hatással vannak (1. ábra).

Mivel a digitalizáció, a kommunikáció fejlődése és a fokozódó környezetvédelmi igények a közlekedési ágazat minden egyes rendsze- rében indukálnak változást, a közúti közlekedésben is megjelennek az innovációk, amelyek újabb és újabb fejlesztéseket indítanak be.

\section{AZ INFRASTRUKTÚRA SZEREPE AZ ÁTALAKULÓ KÖZÚTI KÖZLE- KEDÉSI RENDSZERBEN}

Az úthálózat fejlődése évezredek óta tart, folyamatosan reagálva a változó gazdasági és társadalmi igényekre, követve az egyes korszakok fejlettségi szintjét. Az őskorban kialakult, kitaposott nyomok után, már az időszámításunk előtt megjelentek a burkolt utak (pl. a Római Birodalom kiterjedt úthálózata). A középkorban a korábbi kiterjedt burkolt úthálózat lepusztult. Az európai útépítés jelentősebb korszerüsödése az iparosodott, fejlett országokban az 1700-as években kezdődött meg. Tresaguet/Telford és Macadam pályaszerkezeti megoldásai után az 1850-es években jelent meg az útépítésben a természetes aszfalt, majd a bitumen. A II. világháborút követő nagy újjáépítési hullám és a gépjármü-közlekedés rohamos elterjedése nagyban átalakította az útpályaszerkezetek építési technológiáját [5]. 


\section{Közúti közlekedés}

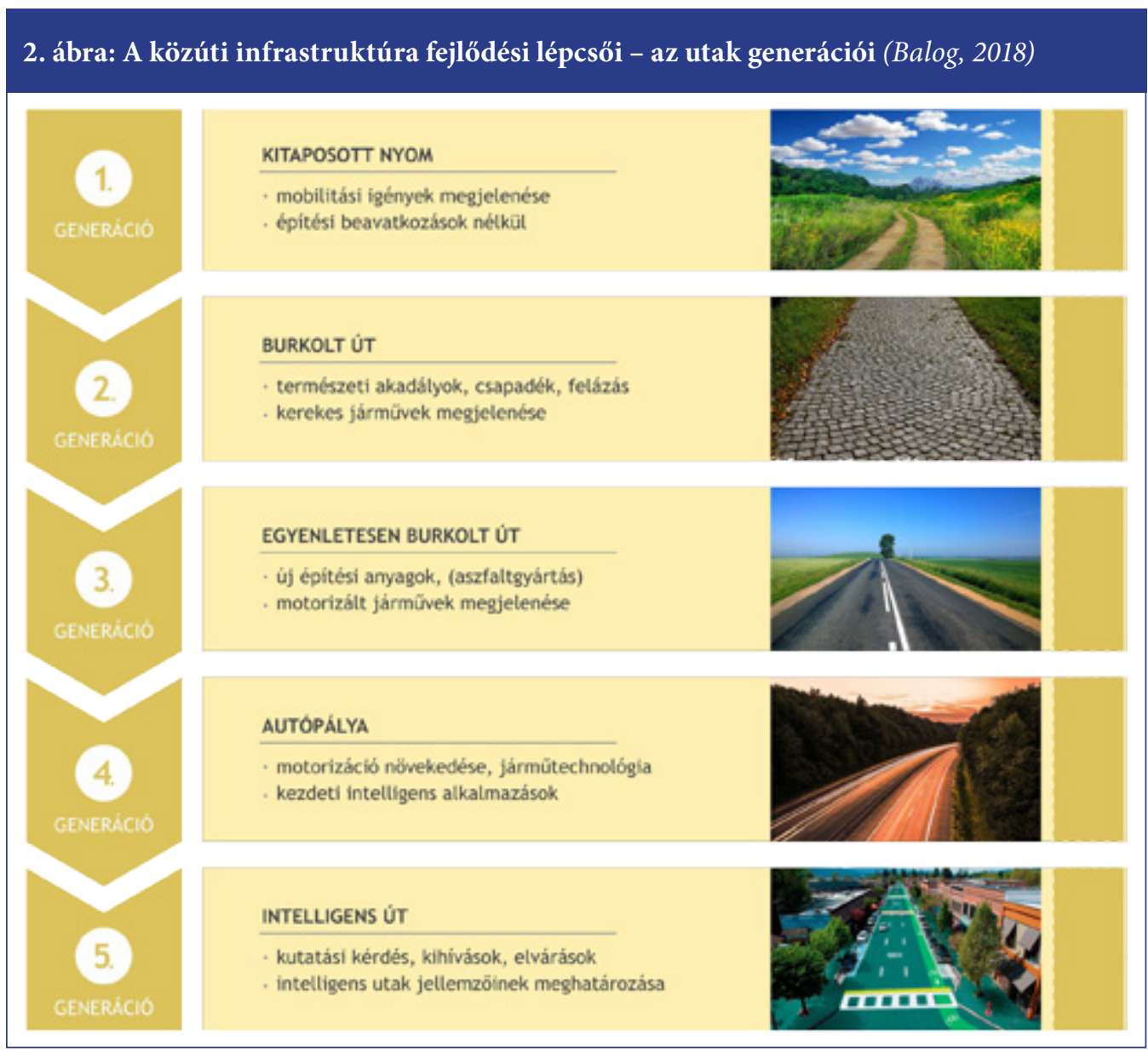

A fejlett országokban növekedett a személygépkocsi állomány és a nehéz teherforgalom aránya, ami először a meglévő úthálózat szélesítését, erősítését, korszerüsítését igényelte. Az 1970-es évektól a fejlett és iparosodott államokban nagy ütemben bővült az autópályahálózat is (2. ábra).

Napjainkban a legújabb kihívások közé tartoznak a klímaváltozás, az extrém időjárási események, a tovább növekvő forgalom, illetve a fenntartással járó felhasználói akadályoztatások csökkentésének igénye. A 21. század ezen kihívásaira ad választ az utak új generációja. Mindezek mellett nem lehet figyelmen kívül hagyni, hogy rendkívül gyorsan fejlödnek az intelligens közlekedési rendszerek. Új megoldásokat alkalmaznak a járműtervezésben, valamint a vezeték nélküli kommunikációban. A kihívások és a műszaki lehetőségek szintézise jelenik meg az utak ötödik generációjában.

A közúti közlekedés, mint rendszer a környezetbe helyezett pálya, jármü és ember egysége. Ezen összetevők kölcsönhatásban fejlődnek már az ember mobilitási igényeinek megjelenése óta [6]. A jármügyártás mennyiségi és minőségi fejlődése fokozta az utazási lehetőségeket. Az új típusú jármüvek és a megnövekedett forgalom elvárásokat támasztanak a közúti infrastruktúra számára, illetve a fejlettebb útpályaszerkezetek és úttartozékok további motivációt adtak a járművek fejlesztéséhez.

A kérdés a közúti közlekedési rendszeren belül, hogy hogyan, milyen új csatornákon érhe- 


\section{3. ábra: Ember-pálya-jármű információs kapcsolatának változása (Balog, 2018)}

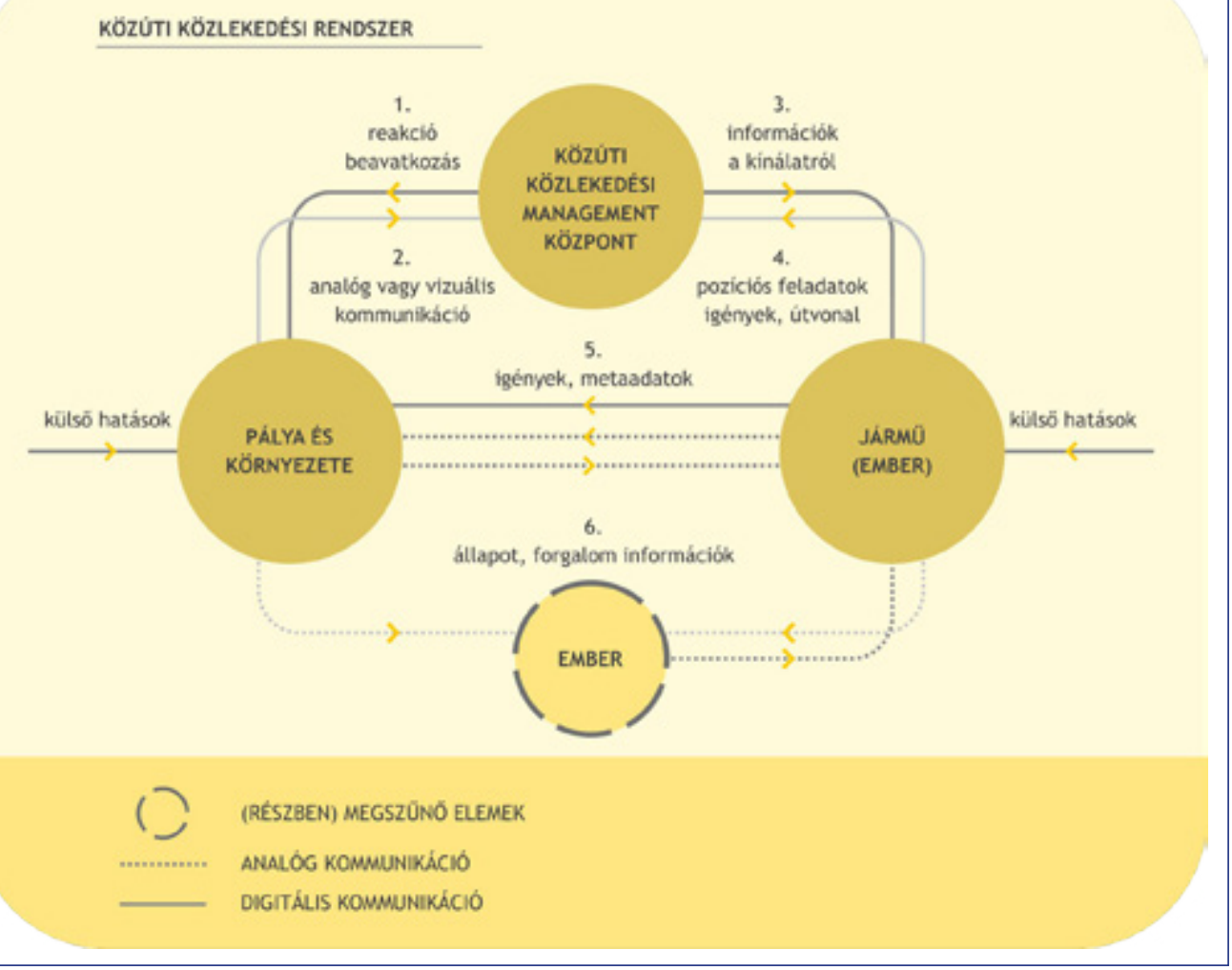

tôk el a járművezetők és milyen jellegű, menynyiségü, minőségű információ szükséges az eredményes befolyásoláshoz, hogy az ember mellett a jármű is képes legyen beavatkozni különböző forgalmi szituációkban. A közúti közlekedési rendszer klasszikusnak tekinthető felosztása olyan alapvető elemeket jelöl meg, amelynek alapjai ma is helytállóak, azonban a technikai, gazdasági és társadalmi fejlődés, a változások napjainkra megkövetelik egy úffajta értelmezését az egyes elemek közötti kapcsolatoknak (3. ábra). Az ember és a jármü, mint rendszerelem egyre inkább összeolvad, ugyanis a korábban a járművezetők felé közvetített információkat ma már a járművek is képesek értelmezni és feldolgozni. A közúti közlekedési menedzsment központok megjelenésével a forgalom lebonyolítása, az infrastruktúra állapota és a járművek információi a valós idejű adatáramlásnak köszönhetően egy helyen kezelhetők. Az ember a rendszerben nem csak közlekedő, hanem az üzemeltető is, így annak teljes megszűnése nagyon hosszú folyamat. Az ember szerepe rövid- és középtávon áttolódik a menedzsment központba.

Ha összevetjük a fejlődő közúti közlekedési rendszer elemeit, láthatóvá válnak azok az aspektusok, amelyeket a korábbi emberpálya-jármü modell nem emel ki. A korábbi modellben az információk érzékelése, továbbítása elsősorban a vizuális érzékelésen alapult. A három elem alkotta rendszerben is megjelent a digitalizáció, az információ kezelésének szükségessége, a monitoring és az adatok közlése, ami egy újfajta, telekommunikáción alapuló kapcsolatot teremt a rendszerelemek között. Az ember szerepét a jármüben a jár- 
műintelligencia veszi át. Alapfeladata megegyezik a humán járművezetőével, biztosítja a zavartalan közlekedés lehetőségét, hiba esetén védelmet jelent az utasok számára. Összességében kiszámíthatóbbá és biztonságosabbá teszi a közlekedést. A telematikai rendszerek fejlődése lehetőséget biztosít, hogy a jármü és vezetője több, célzott információt kapjon a közlekedési folyamatokról. Az információ öszszefügghet az útüzemeltetéssel, az útvonaltervezéssel, a baleseti helyzettel, vagy akár vonatkozhat az időjárásra.

\section{AZ ÚJ GENERÁCIÓS UTAK JEL- LEMZÖINEK AZONOSÍTÁSA}

Az átalakuló közúti közlekedési rendszerben az új generációs pályaszerkezetek és a közúti infrastruktúra tulajdonságai is megváltoznak. Azonosításukat a változásokat kiváltó tényezők meghatározásával és részletes elemzésével lehet hatékonyan, pontosan elvégezni. A tulajdonságok, jellemzők feltárása és megismerése a későbbiekben a megfelelő technológiai és müszaki megoldások hozzárendelését teszi lehetővé.

\subsection{Közvetlen és közvetett hatások}

Az új generációs pályaszerkezetek és a közúti infrastruktúra fejlesztése során közvetlen és közvetett hatások nevezhetők meg, amelyek meghatározzák az infrastruktúra egyes elemeinek fejlődési irányait. A hatásokat következőképpen lehet meghatározni:

- közvetlen hatások, amelyek a közlekedési alágazat mellett más ipari és gazdasági ágazatokban is jelentős innovációs folyamatokat indítanak be;

- közvetett hatások, amelyek a közúti közlekedési rendszer elemei változásának eredményei.

A hatások nemcsak kielégítendő igényeket határoznak meg, hanem lehetséges technológiai megoldásokat is feltárnak (4. ábra). A következő nagy, közvetlen tényezőket lehet megnevezni [7]:

- digitalizáció és kommunikáció;

- környezetvédelem.

A digitalizációs és a kommunikációs technológiák fejlődésének eredményei már megjelen- tek a közlekedési alágazatok különböző területein. Példaként említhetők az utazás tervező és optimalizáló alkalmazások vagy a forgalmi jellemzőket megfigyelő és elemző rendszerek. Az infrastruktúra esetében ezeknek a technológiáknak az adatok gyüjtésében, tárolásában, továbbításában és szolgáltatásában (az információk elöállításban) van szerepük. Az ötödik generációs pályaszerkezetekkel szemben elvárás, hogy szerkezetükben vagy felületükön elhelyezhetők legyenek az adatgyüjtésre és továbbításra alkalmas hardver elemek. Ezek kapcsolódjanak egymáshoz és egy központi adatbázishoz. Az információk áramlását nagy kapacitású és magas szintű rendelkezésre állású kommunikációs csatornák biztosítják az infrastruktúra és a „fogadó elemek” (központ, jármüvek) között.

A közvetlen hatások fejlesztési irányokat és szempontokat is megfogalmaznak, de biztosítják a megfelelő technológiát is az infrastruktúra-fejlesztéshez:

- Internet of Things (IoT, azaz „dolgok internete”),

- felhőszolgáltatások,

- szenzortechnológia.

A környezetvédelem területén az infrastruktúrának is alkalmazkodni kell a globális trendekhez. A pályaszerkezetek és a közúti tartozékok gyártása során előtérbe kerülnek a zéró emissziós folyamatok és a nagy mennyiségben újrahasznosított, valamint környezetkímélő anyagokat alkalmazó technológiák [8], figyelembe véve a folyamatosan változó klimatikus viszonyokat. Így kiemelt jelentőséggel bír az időjárási szélsőségek kezelése (pl. intenzívebb csapadékesemények). A rezgés- és zajcsillapítás olyan terület, ami az elkövetkezendő években továbbra is kiemelt figyelmet kap az élhetőbb és emberközpontúbb városi környezet kialakítása érdekében.

A járműtechnológiai fejlesztések a közvetett hatások csoportjába tartoznak, mert ezeket ugyanúgy a közvetlen, globális hatások váltják $\mathrm{ki}$, azonban önmagukban is egyedi igényeket jelenítenek meg a közúti infrastruktúra fejlesztésében. Az újszerü gépjármütechnológiák a közvetlen hatások első megjelenései a közúti 
4. ábra: Az új generációs pályaszerkezetek fejlődését indukáló közvetlen és

közvetett tényezők (Balog, 2018)

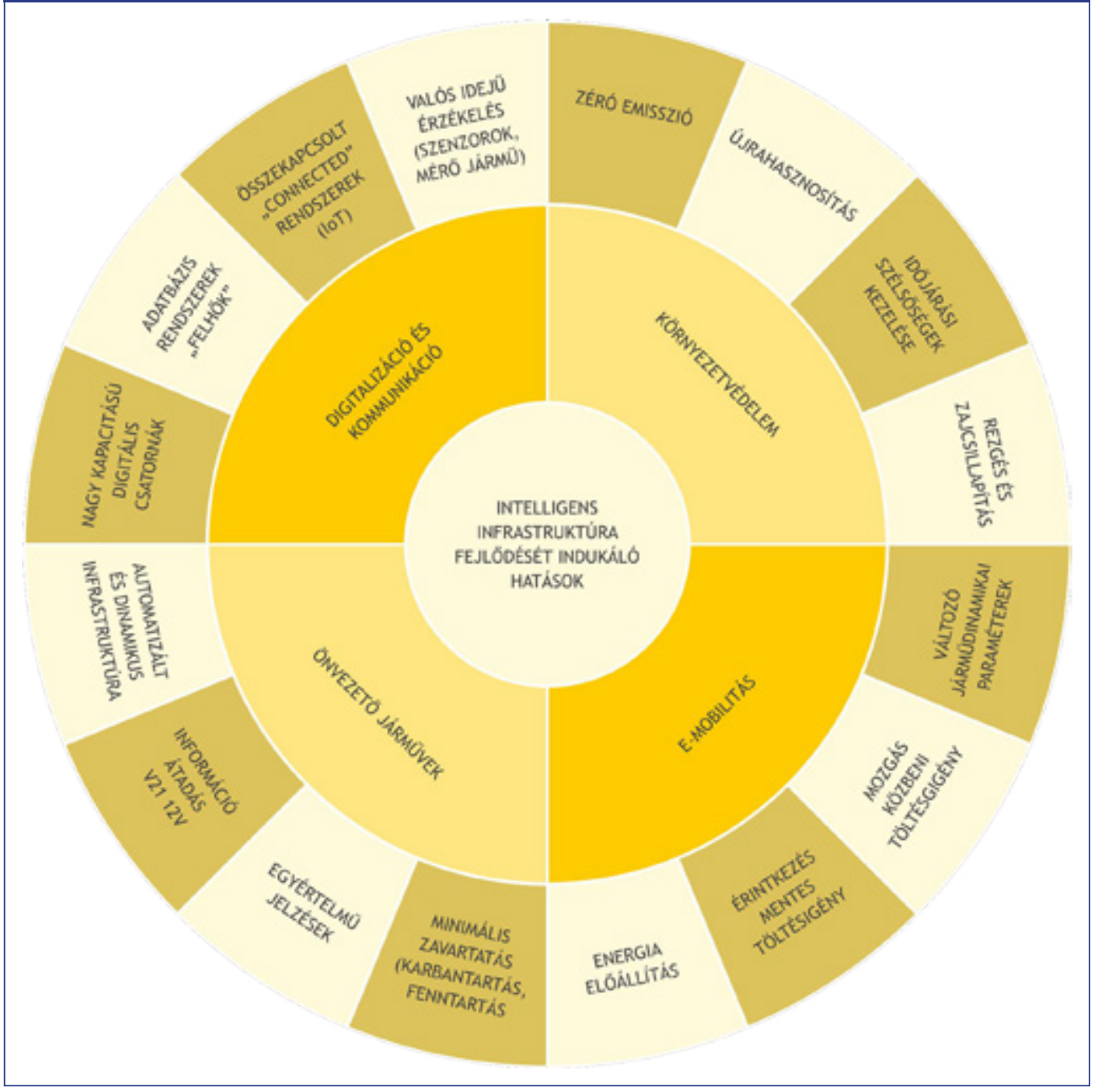

közlekedési rendszerben. Az új típusú jármüvek hatékony működését az infrastruktúra biztosítja, így a járművek fejlesztési irányait az infrastruktúra innovációi is követik.

$\mathrm{Az}$ egyes hatások megjelenése a gépjármütechnológiák területén:

- elektromos jármühajtás,

- önvezető és automata jármüirányítás.

Az elektromobilitás legfőbb műszaki korlátját az akkumulátor technológia jelenlegi fejlettsé- gi szintje képezi [9]. A tárolható energia menynyisége, az elektromos módban megtehető utazások távolsága korlátozott. Az akkumulátorok súlya nagy és áruk jelenleg igen magas. $\mathrm{Az}$ akkumulátor technológia lassan fejlődik, így előtérbe kerültek a gyakoribb vagy a folyamatos, a menet közbeni töltést megvalósító technológiák fejlesztései [10]. A mozgás közbeni töltési lehetőségek biztosíthatják a szabad mobilitást. Az érintkezés nélküli kapcsolat az elektromos jármű számára biztonságos és kényelmes töltési lehetőséget adna. 


\section{Közúti közlekedés}

5. ábra: Az ötödik generációs utak jellemzőit összefoglaló Mandala-ábra

(Balog, 2018)

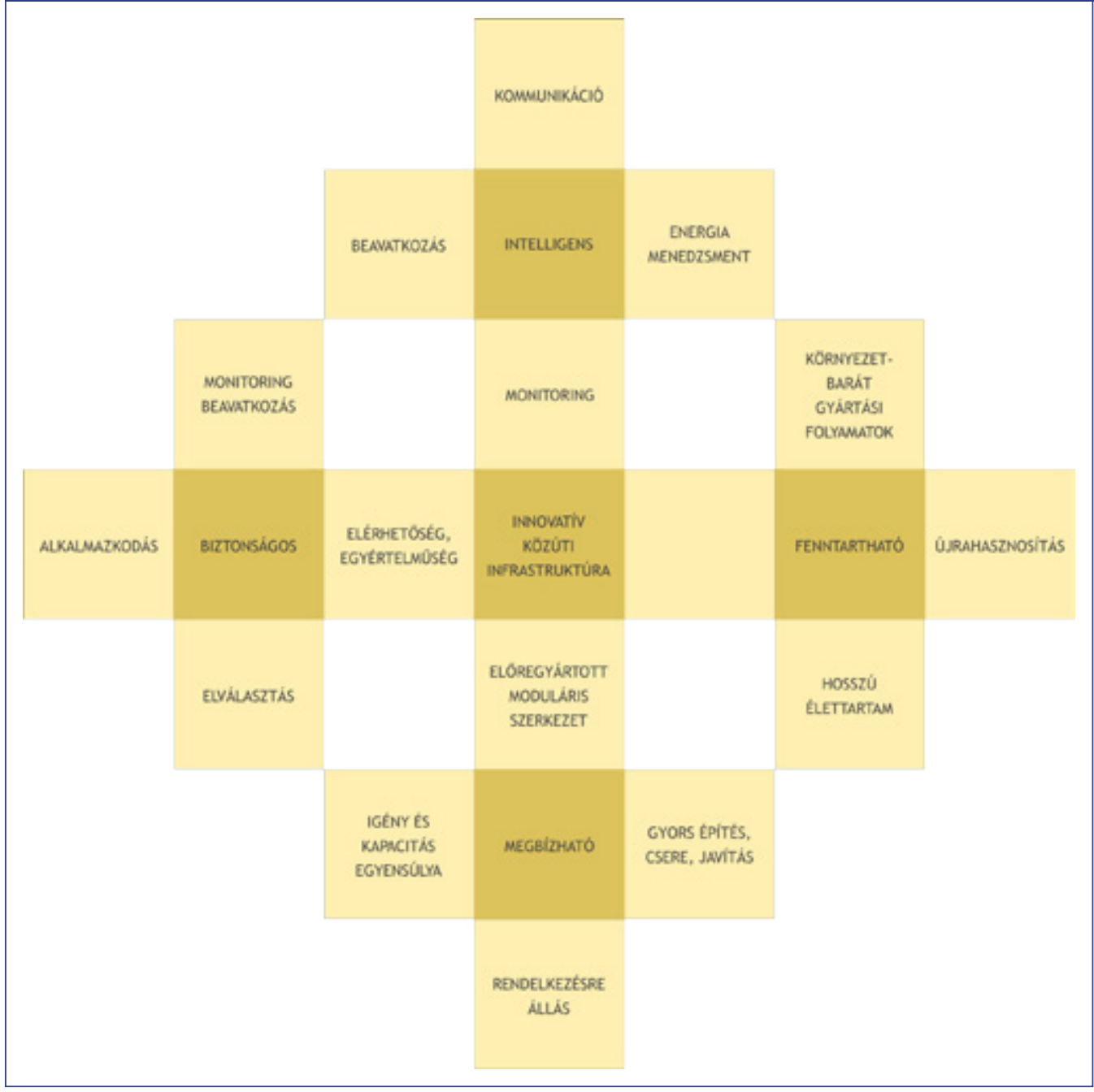

$\mathrm{Az}$ érintkezésmentes töltőberendezéseket tartalmazó utak, amíg azon nem elektromos jármü közlekedik, hagyományos útként funkcionálnak. Fontos szempont, hogy a közlekedéshez szükséges energiát az infrastruktúra minél nagyobb mértékben saját maga állítsa elő, így előtérbe kerülnek az olyan burkolatok fejlesztései, amelyek napelemes vagy piezoelektromos módon állítanak elő energiát.

Közlekedési alágazati szinten az autonóm jármüvek fejlesztése jelenleg leginkább az intelli- gens közlekedési rendszerekre van hatással [11], ahol megjelennek az intelligens közlekedési infrastruktúrák is. Ezek az intelligens funkciókkal rendelkező vagy teljesen automata jármüvekkel egy komplex rendszert hoznak létre. Az új generációs infrastruktúra egyértelmü jelzéseket biztosít a járművek számára, hogy azokat hiba nélkül tudják feldolgozni. Ezek az információk érkezhetnek digitálisan vagy vizuális jelzés alapján. A vizuális jelzések (jelzőtáblák, burkolati jelek) esetében a dinamikus változtathatóság jelenti a fejlesztések elsődleges irányát. 


\subsection{A közúti infrastruktúra új jellemzői}

A közvetlen és közvetett hatásokból levezetett fejlesztési igények alapján határozhatók meg az új generációs közúti infrastruktúra alapjellemzői (5. ábra). Az innovatív utak alapjellemzői (világossárga mezők) négy fö tulajdonság (sötétsárga mezők) köré csoportosíthatók:

- fenntartható közút: magas fokú újrahasznosítás, környezetbarát gyártási folyamatok,

- intelligens közút: adatokat gyüjt, feldolgoz, majd dönt és beavatkozik (pl. hömérsékleti adatok gyüjtése, továbbítása automata jégmentesítő berendezés felé),

- biztonságos közút: növekvő forgalom és sebesség mellett csökkenti a balesetek kockázatát;

- megbízható közút: hosszú élettartam, de meghibásodás esetén gyors és egyszerü beavatkozás lehetséges (pl. moduláris elemek cseréje).

A fenntartható közút minimalizálja a közlekedésből eredő környezeti terhelést. Az építés során olyan anyagokat alkalmaznak, amelyek általában különböző építési és kommunális forrásból származó visszanyert anyagok. A gyártási folyamatok során fokozottan érvényesülnek a zéró emissziós célkitüzések. Mindezek mellett hosszú élettartamot garantálnak, így a forgalom minimális zavartatása érhető el (minimális fenntartási és felújítási munkákra van szükség).

A megbízható infrastruktúra feltétele a magas szintü rendelkezésre állás, gyors építést, egyes elemek cseréjét, javítását lehetővé téve. Ezek a tulajdonságok elsősorban előregyártott, moduláris szerkezetekkel valósíthatók meg. $\mathrm{Az}$ elöregyártásnak köszönhetően az egyes elemek üzemi körülmények között készülnek el, amelyek így magas szavatosságot és minőséget garantálnak.

$\mathrm{Az}$ intelligens tulajdonság valósítja meg a közúti pályaszerkezetek és infrastruktúra illeszkedését az ITS rendszerekbe, olyan hardver és szoftver elemek által, amelyek képesek érzékelni, megfigyelni a különleges közlekedési helyzeteket, eseményeket, illetve saját állapotukat is meghatározzák. Az elöállított adatok továbbításához rendelkeznek megfelelő kommunikációs technológiákkal. A kapott információk alapján beavatkoznak a közlekedés és az infrastruktúra üzemeltetési folyamataiba.

Az önvezető járművek és az elektromobilitás terjedésének hatására átalakulnak a jármüvek mozgásának dinamikai jellemzői. Emiatt az infrastruktúra biztonsági jellemzői is megváltoznak. A jelzőtáblák, a burkolati jelek, az elválasztó rendszerek esetében is elötérbe kerülnek azok a megoldások, amelyek valós idejü információt közölnek.

Az 5. ábra a négy fö tulajdonság között kapcsolódási pontokat, metszeteket is meghatároz. Az energetikai folyamatok menedzselése (napelemes burkolatok, elektromos járművek töltése) intelligens tulajdonsága az infrastruktúrának, de hozzájárul a közúti közlekedés környezeti fenntarthatóságának növeléséhez is. Az intelligens utak automata-autonóm módon a forgalmi és környezeti viszonyok ismeretében különböző üzemeltetési folyamatok (sebesség korlátozása, úttisztítás, jégmentesítés) végrehajtására képesek, amelyek hozzájárulnak a forgalombiztonság fenntartásához is. A hosszú élettartamú infrastruktúra megvalósítását az előregyártott, moduláris szerkezetek teszik lehetővé, amelyek építése, javítása, karbantartása gyorsan elvégezhető.

\section{4. ÖSSZEFOGLALÁS}

A közúti pályaszerkezetek és infrastruktúra új generációi összetett szempontok alapján határozandók meg. A közutak már nem csak közlekedési felületek lesznek, hanem részei egy komplex intelligens közúti közlekedési rendszernek. A közúti infrastruktúra új generációja szolgálja ki az innovatív jármütechnológiákat. A komplex rendszerelemek megvalósításához már nem elegendő egy-egy szakterület ismerete (pl. burkolattervezés önállóan), sokkal inkább az egyes mérnöki ismeretek (közlekedésmérnöki, villamosmérnöki, építőmérnöki) összehangolása szükséges. 


\section{KÖSZÖNETNYILVÁNÍTÁS}

EFOP-3.6.3-VEKOP-16-2017-00001: Tehetséggondozás és kutatói utánpótlás fejlesztése autonóm jármüirányítási technológiák területén - A projekt a Magyar Állam és az Európai Unió támogatásával, az Európai Szociális Alap társfinanszírozásával valósul meg.

A tanulmány alapjául szolgáló kutatást az Emberi Erőforrások Minisztériuma által meghirdetett Felsőoktatási Intézményi Kiválósági Program támogatta, a Budapesti Müszaki és Gazdaságtudományi Egyetem Mesterséges Intelligencia (BME FIKP-MI/FM) tématerületi programja keretében.

\section{FELHASZNÁLT IRODALOM}

[1] Balog Péter Új generációs pályaszerkezetek és innovatív közúti infrastruktúra. Infrastruktúra-építőmérnök mesterképzés diplomamunka dolgozat, Budapesti Müszaki és Gazdaságtudományi Egyetem, Építőmérnöki Kar, 2018

[2] Az Európai Parlament és a Tanács 2010/40/ EU Irányelve az intelligens közlekedési rendszereknek a közúti közlekedés területén történő kiépítésére, valamint a más közlekedési módokhoz való kapcsolódására vonatkozó keretről. (2010. július 7.) (https://eur-lex.europa.eu/legal-content/ HU/TXT/?uri=LEGISSUM\%3Atr0040)

[3] Az Európai Parlament és a Tanács 2014/94/EU Irányelve az alternatív üzemanyagok infrastruktúrájának kiépítéséről. (2014. október 22.) (https:// eur-lex.europa.eu/legal-content/HU/ ALL/?uri=celex\%3A32014L0094)
[4] Az Európai Parlament és a Tanács 2008/98/EK Irányelve a hulladékokról és egyes irányelvek hatályon kívül helyezéséröl. (2008. november 19.) (https:// eur-lex.europa.eu/legal-content/HU/ ALL/?uri=CELEX\%3A32008L0098)

[5] Dr. Nemesdy Ervin Útpályaszerkezetek (Útépítéstan II.), Tankönyvkiadó, Budapest, Magyarország, (1989). ISBN 9631821048

[6] Dr. Koller Sándor Forgalomtechnika, Tankönyvkiadó, Budapest, Magyarország, (1976). ISBN 05190000255766

[7] Balog Péter, Dr. Tóth Csaba, Dr. Csiszár Csaba (2018): Új generációs közutak a fejlődő jármütechnológiák tükrében, XXII. Nemzetközi Építéstudományi Konferencia kiadványa, Csíksomlyó, Erdély, Románia, 2018.05.31.-2018.06.03., pp. 15-17., ISSN 1843-2123

[8] Dr. Tóth Csaba, Soós Zoltán (2016): A „fenntartható" útpályaszerkezetek: Környezettudatosan tervezett útburkolatok és közutak, Innotéka Mélyépítés Vol. 2, No. 2, pp. 4-7.

[9] Csonka Bálint, Csiszár Csaba (2017): Determination of Charging Infrastructure Locations for Electric Vehicles, Transportation Research Procedia, Vol. 27, No. 1, pp. 768-775.DOI: http://doi.org/cvtd

[10] Nádasi Réka (2017): Villamosított utak életciklus elemzése, Útügyi Lapok, Vol. 5 No. 10, pp. 5-14., ISSN 2064-0919

[11] Csiszár Csaba, Földes Dávid (2018): System model for autonomous road freight transportation, Promet-Traffic \& Transportation, Vol. 30 No. 1, pp. 93-103. DOI: http://doi.org/cvtc

\title{
E számunk lektorai
}

\author{
Bretz Gyula - Dr. Katona András
}

Tánczos Lászlóné dr. - Dr. Tóth János 


\section{Közúti közlekedés}

\section{Exploring the Characteristics of New Generation Road Pavements}

The road transport system is currently undergoing significant changes. The development of elements and subsystems is also impacted by external, environmental and internal vehicle-roadhuman interactions. Accordingly, the roadway structure and the innovation of infrastructure are fundamentally influenced by current technology and vehicle developments. In Hungary, the knowledge of intelligent track structures is still incomplete, so this research is aimed at studying and analyzing international research and development experiences to facilitate domestic adaptation. After reviewing the scientific literature, we identified the factors influencing the characteristics of the road infrastructure and determined the properties of new generation road structures. The results will assist the development of the regulatory environment of the domestic smart roads (e.g. Road Engineering Standards).

\section{Die Erforschung der Eigenschaften von Fahrbahnstrukturen der neuen Generation}

Das Straßentransportsystem unterliegt derzeit erheblichen Veränderungen. Die Entwicklung von Elementen und Subsystemen wird auch durch externe, umweltbedingte und interne Interaktionen zwischen Fahrzeug, Straße und Mensch beeinflusst. Dementsprechend werden die Fahrbahnstruktur und die Innovation der Infrastruktur grundlegend von aktuellen Technologie- und Fahrzeugentwicklungen beeinflusst. In Ungarn ist das Wissen über intelligente Fahrbahnstrukturen noch unvollständig. Daher zielt diese Forschung darauf $a b$, internationale Forschungsund Entwicklungserfahrungen zu untersuchen und zu analysieren, um ihre Adaptation in Ungarn zu erleichtern. Nach dem Überblick der wissenschaftlichen Literatur haben wir die Faktoren identifiziert, die die Eigenschaften der Straßeninfrastruktur beeinflussen, und die Eigenschaften der Fahrbahnstrukturen der neuen Generation bestimmen. Die Ergebnisse werden die Entwicklung des regulatorischen Umfelds der inländischen Smart-Strassen unterstützen (z. B. Technische Vorschriften im Strassenwesen). 